\title{
Amino Acid Substitution in HCV Core/NS5A Region and Genetic Variation Near IL28B Gene Affect Treatment Efficacy to Interferon plus Ribavirin Combination Therapy
}

\author{
Norio Akuta ${ }^{a}$ Fumitaka Suzuki $^{a}$ Miharu Hirakawa ${ }^{a}$ Yusuke Kawamura ${ }^{a}$ \\ Hitomi Sezaki $^{a}$ Yoshiyuki Suzuki ${ }^{a}$ Tetsuya Hosaka ${ }^{a}$ Masahiro Kobayashia \\ ${\text { Mariko Kobayashib }{ }^{b} \text { Satoshi Saitoh }}^{a}$ Yasuji Arase $^{a} \quad K^{2}$ ji Ikeda ${ }^{a}$ \\ Kazuaki Chayamac Yusuke Nakamurad Hiromitsu Kumada ${ }^{\mathrm{a}}$
}

a Department of Hepatology, and biver Research Laboratory, Toranomon Hospital, Tokyo, 'Department of Medical and Molecular Science, Division of Frontier Medical Science, Programs for Biomedical Research, Graduate School of Biomedical Science, Hiroshima University, Hiroshima, and d Laboratory of Molecular Medicine, Human Genome Center, Institute of Medical Science, University of Tokyo, Tokyo, Japan

\section{Key Words}

Hepatitis C virus - Interferon - Ribavirin · Core region • NS5A region $\cdot I S D R \cdot I R R D R \cdot I L 28 B$

\begin{abstract}
Objective: To evaluate predictive factors of treatment efficacy to interferon (IFN)/ribavirin in patients infected with HCV genotype 1b (HCV-1b). Methods: This study investigated pretreatment predictors, including viral- (aa substitutions in core aa 70/91 and NS5A-ISDR/IRRDR) and host-related factors (genetic variation near IL28B gene), to 48-week IFN/ribavirin in 490 Japanese adults infected with HCV-1b. Results: The proportion of patients who showed end-of-treatment response (ETR), sustained virological response (SVR), and SVR after ETR was 76, 54, and 76\%, respectively. There was a significant positive correlation between the number of aa substitutions in ISDR and those in IRRDR. Concerning the substitution of core aa 91, the number of aa substitutions in ISDR/IRRDR of patients with Leu91 was significantly higher
\end{abstract}

than that of patients with Met91. Furthermore, levels of viremia were influenced by aa substitutions in core aa 91 and ISDR/IRRDR. By multivariate analysis, rs8099917 genotype was an important predictor of ETR and SVR. With regard to viral factors, core aa 70/91 was an important predictor of ETR, and SVR after ETR. ISDR was an important predictor of SVR, and SVR after ETR. Conclusion: aa substitution in core/NS5A region and genetic variation near IL28B were important predictors of treatment efficacy to IFN/ribavirin.

Copyright $\odot 2011$ S. Karger AG, Basel

\section{Introduction}

Treatment of chronic hepatitis $\mathrm{C}$ virus (HCV) infection with interferon (IFN) combined with ribavirin carries potential serious side effects and is costly, especially when used long enough to achieve a high sustained virological response (SVR) in patients infected with HCV genotype $1 \mathrm{~b}(\mathrm{HCV}-1 \mathrm{~b})$ and high viral loads. For these rea-

\section{KARGER}

Fax +41613061234 E-Mail karger@karger.ch www.karger.com
(C) 2011 S. Karger AG, Basel

$0300-5526 / 12 / 0553-0231 \$ 38.00 / 0$

Accessible online at:

www.karger.com/int
Norio Akuta, MD

Department of Hepatology, Toranomon Hospital

2-2-2 Toranomon, Minato-ku

Tokyo 105-0001 (Japan)

Tel. +81 44877 5111, E-Mail akuta-gi@ umin.ac.jp 
sons, those patients who do not achieve SVR need to be identified, so as to free them of unnecessary side effects and reduce costs, preferably before the start of the combination therapy.

Viral- and host-related factors are useful as predictors of treatment efficacy to 48-week IFN/ribavirin combination therapy. With regard to viral factors, amino acid (aa) substitutions at position 70 and/or 91 in the core region of HCV-1b are pretreatment predictors of virological response to combination therapy [1-4], and also affect clinical outcome, including hepatocarcinogenesis $[5,6]$. Furthermore, the NS5A region of $\mathrm{HCV}-1 \mathrm{~b}$, including IFNsensitivity-determining region (ISDR) $[7,8]$ and IFN/ ribavirin resistance-determining region (IRRDR) [9, 10], are also useful as pretreatment predictors of virological response to combination therapy $[11,12]$. With regard to host factors, genetic variations near IL28B gene (rs8099917, rs12979860) on chromosome 19, which encodes IFN- $\lambda-3$, are pretreatment predictors of virological response to combination therapy in individuals infected with HCV-1 [13-16], and also affect clinical outcome, including spontaneous clearance of $\mathrm{HCV}$ [17]. A recent report identified genetic variation near $I L 28 B$ gene and aa substitution of the core region as predictors of SVR to triple therapy of telaprevir/pegylated (PEG)-IFN/ribavirin in Japanese patients infected with HCV-1b [18]. However, to our knowledge, there are no previous reports of IFN/ribavirin combination therapy based on multivariate analysis to investigate pretreatment predictors, including all of aa substitutions in core aa 70/91 and NS5AISDR/IRRDR, and genetic variation near IL28B gene.

The aim of the present study was to investigate predictive factors of treatment efficacy, including viral- (aa substitutions in core aa 70/91 and NS5A-ISDR/IRRDR) and host-related factors (genetic variation near IL28B gene), to 48 -week IFN/ribavirin in Japanese adults infected with HCV-1b.

\section{Patients and Methods}

\section{Study Population}

A total of 1,249 HCV-1b-infected Japanese adult patients were consecutively recruited into the study protocol of combination therapy with IFN (PEG-IFN $\alpha-2 b$ or IFN $\alpha-2 b$ ) plus ribavirin between December 2001 and January 2009 at Toranomon Hospital, Tokyo, Japan. Among these, 490 patients, who could complete a total of 48 weeks of combination therapy, were enrolled in this retrospective study, and fulfilled the following criteria: (1) negativity for hepatitis B surface antigen (HBsAg) in serum; (2) HCV$1 \mathrm{~b}$ only confirmed by sequence analysis; (3) HCV-RNA levels of $\geq 5.0 \log \mathrm{IU} / \mathrm{ml}$ determined by the COBAS TaqMan HCV test
(Roche Diagnostics, Tokyo, Japan) within the preceding 2 months of enrolment; (4) no hepatocellular carcinoma; (5) body weight $>40 \mathrm{~kg}$; (6) lack of coinfection with human immunodeficiency virus; (7) no previous treatment with antiviral or immunosuppressive agents within the preceding 3 months of enrolment; (8) none was an alcoholic; lifetime cumulative alcohol intake was $<500 \mathrm{~kg}$; (9) none had other forms of liver diseases, such as hemochromatosis, Wilson disease, primary biliary cirrhosis, alcoholic liver disease, or autoimmune liver disease, and (10) none of the females was pregnant or breastfeeding.

The study protocol was in compliance with the Good Clinical Practice Guidelines and the 1975 Declaration of Helsinki, and was approved by the institutional review board. Each patient gave their informed consent before participating in this trial.

The treatment efficacy was evaluated in terms of HCV-RNA negativity at the end of treatment (end-of-treatment response (ETR)) and 24 weeks after the completion of therapy (SVR), based on the COBAS TaqMan HCV test (Roche Diagnostics). SVR in patients who achieved ETR was defined as SVR after ETR. ETR, SVR, and SVR after ETR could be evaluated in 487 (99\%), 448 $(91 \%)$, and $321(66 \%)$ of 490 patients, respectively.

$422(86 \%)$ patients received PEG-IFN $\alpha-2 b$ at a median dose of $1.4 \mu \mathrm{g} / \mathrm{kg}$ (range 0.7-1.9) subcutaneously each week plus oral ribavirin at a median dose of $11.1 \mathrm{mg} / \mathrm{kg}$ (range 3.7-15.1) daily for 48 weeks. The remaining $68(14 \%)$ patients received 6 million units of IFN $\alpha$-2b intramuscularly each day for 48 weeks (daily for the initial 2 weeks, followed by three times per week for 46 weeks), and oral ribavirin at a median dose of $11.3 \mathrm{mg} / \mathrm{kg}$ (range 6.8-13.4) daily for 48 weeks.

Table 1 summarizes the profiles and laboratory data of the 490 patients at the commencement of treatment. They included 310 males and 180 females aged $20-75$ years (median 54 ).

\section{Measurement of HCV RNA}

The antiviral effects of treatment on HCV were assessed by measuring plasma HCV-RNA levels. In this study, HCV-RNA levels were evaluated at least once every month before, during, and after therapy. HCV-RNA concentrations were determined using the COBAS TaqMan HCV test (Roche Diagnostics). The linear dynamic range of the assay was $1.2-7.8 \mathrm{log} \mathrm{IU} / \mathrm{ml}$, and the undetectable samples were defined as negative.

\section{Detection of a Substitutions in Core, and NS5A Regions of}

$\mathrm{HCV}-1 b$

With the use of HCV-J (accession No. D90208) as a reference [19], the sequence of 1-191 aa in the core protein of HCV-1b was determined and then compared with the consensus sequence constructed on the previous study to detect substitutions at aa 70 of arginine (Arg70) or glutamine/histidine (Gln70/His70) and aa 91 of leucine (Leu91) or methionine (Met91) [1]. The sequence of 2,209-2,248 aa in the NS5A of HCV-1b (ISDR) reported by Enomoto et al. [7, 8] was determined, and the number of aa substitutions in ISDR was defined as wild-type (WT) $(0,1)$ or non-wildtype (non-WT) $(\geq 2)$ in comparison with HCV-J. Furthermore, the sequence of 2,334-2,379 aa in the NS5A of HCV-1b (IRRDR) reported by El-Shamy et al. $[9,10]$ was determined and then compared with the consensus sequence constructed on the previous study. In the present study, aa substitutions of the core region and NS5A-ISDR/IRRDR of HCV-1b were analyzed by direct sequencing $[10,18]$. 
Genetic Variation near IL28B Gene

Samples for genome-wide association survey were genotyped using the Illumina HumanHap610-Quad Genotyping BeadChip. Genotyping data were subjected to quality control before the data analysis. Genotyping for replication and fine mapping was performed by use of Invader assay, TaqMan assay, or direct sequencing as described previously $[20,21]$.

In this study, genetic variations near IL28B gene (rs8099917), reported as the pretreatment predictors of treatment efficacy in Japanese patients $[14,18]$, were investigated.

\section{Statistical Analysis}

Non-parametric tests (Mann-Whitney U test, $\chi^{2}$ test and Fisher's exact probability test) were used to compare the characteristics of the groups. Correlation analysis was evaluated by the Spearman rank correlation test. Uni- and multivariate logistic regression analyses were used to determine those factors that significantly contributed to ETR, SVR, and SVR after ETR. The odds ratios (OR) and $95 \%$ confidence intervals (95\% CI) were also calculated. All p values $<0.05$ by the two-tailed test were considered significant. Variables that achieved statistical significance $(\mathrm{p}<0.05)$ on univariate analysis were entered into multiple logistic regression analysis to identify significant independent predictive factors. Each variable was transformed into categorical data consisting of two simple ordinal numbers for uni- and multivariate analyses. Potential predictive factors associated with ETR, SVR, and SVR after ETR included the following variables: sex, age, history of blood transfusion, familial history of liver disease, body mass index, aspartate aminotransferase (AST), alanine aminotransferase (ALT), albumin, $\gamma$-glutamyl transpeptidase (GGT), leukocyte count, hemoglobin, platelet count, level of viremia, $\alpha$-fetoprotein, total cholesterol, high-density lipoprotein cholesterol, low-density lipoprotein cholesterol, triglycerides, uric acid, ribavirin dose/body weight, genetic variation near $I L 28 B$ gene, and aa substitution in the core region, and NS5A-ISDR/IRRDR. Statistical analyses were performed using SPSS software (SPSS Inc., Chicago, Ill., USA).

\section{Results}

\section{Response to Therapy}

ETR was achieved by 372 of 487 (76\%) patients, SVR by 244 of 448 (54\%), and SVR after ETR by 244 of 321 (76\%).

\section{Number of a Substitutions in NS5A-ISDR and NS5A- IRRDR}

As a whole, 0,1 , and $\geq 2$ aa substitutions in ISDR were found in 56\% (227 of 406), 23\% (95 of 406), and 21\% (84 of 406) of patients, respectively. Thus, the percentage of patients with $\leq 1$ aa substitution in ISDR (WT) was 79\% (322 of 406). Furthermore, $\leq 3,4-5$, and $\geq 6$ aa substitutions in IRRDR were found in 36\% (73 of 200), 34\% (67 of 200 ), and $30 \%$ (60 of 200 ) of patients, respectively (fig. 1).

Core/NS5A and IL28B Affect Treatment
Table 1. Patient profile and laboratory data at commencement of the 48-week combination therapy of IFN + ribavirin in 490 patients infected with $\mathrm{HCV}-1 \mathrm{~b}$

\section{Demographic data}

Number of patients

Male/female

490

Age, years

History of blood transfusion

Family history of liver disease

Body mass index, $\mathrm{kg} / \mathrm{m}^{2}$

$310 / 180$

$54(20-75)$

$169(34 \%)$

$96(20 \%)$

$22.6(15.7-34.7)$

\section{Laboratory data}

Level of viremia, $\log \mathrm{IU} / \mathrm{ml}$

$6.4(2.2-7.7)$

Serum AST, IU/l

$50(16-296)$

Serum ALT, IU/l

Serum albumin, $\mathrm{g} / \mathrm{dl}$

GGT, IU/l

Leukocyte count, $\mathrm{n} / \mathrm{mm}^{3}$

$67(12-836)$

$3.9(3.1-4.7)$

$44(10-592)$

4,700

Hemoglobin, g/dl

Platelet count, $\times 10^{4} / \mathrm{mm}^{3}$

$(1,200-10,900)$

$14.4(10.6-18.1)$

$\alpha$-Fetoprotein, $\mu \mathrm{g} / \mathrm{l}$

Total cholesterol, mg/dl

$16.7(6.4-37.5)$

$5(1-459)$

High-density lipoprotein cholesterol, mg/dl

Low-density lipoprotein cholesterol, $\mathrm{mg} / \mathrm{dl}$

$170(96-284)$

$46(13-95)$

$100(32-190)$

Triglycerides, $\mathrm{mg} / \mathrm{d}$ l

$90(33-416)$

Uric acid, $\mathrm{mg} / \mathrm{dl}$ $5.5(2.3-9.4)$

\section{Treatment}

PEG-IFN $\alpha-2 b / I F N \alpha-2 b$

$422 / 68$

Ribavirin dose, $\mathrm{mg} / \mathrm{kg}$

$11.2(3.7-15.1)$

\section{a substitutions in the $\mathrm{HCV}-1 \mathrm{~b}$}

Core aa 70, arginine/glutamine (histidine) 266/15

Core aa 91, leucine/methionine

ISDR of NS5A, $0 / 1 / \geq 2$

$246 / 169$

$227 / 95 / 84$

IRRDR of NS5A, $\leq 3 / 4-5 / \geq 6$

$73 / 67 / 60$

Genetic variation near IL28B gene

rs8099917 genotype, TT/TG/GG

$150 / 65 / 4$

Data represent number of patients with percentages in parentheses, or median (range) values.

The correlation between ISDR and IRRDR was analyzed. There was a significant positive correlation between the number of aa substitutions in ISDR and those in IRRDR $(r=0.308, p<0.001)$ (fig. 2).

\section{aa Substitutions in the Core Region and NS5A-ISDR/ IRRDR}

Concerning the substitution of core aa 70 , the number of aa substitutions in ISDR of 256 patients with Arg70 (median 0) was not significantly different from that of 146 patients with Gln70 (His70) (median 0) (fig. 3a). Fur- 


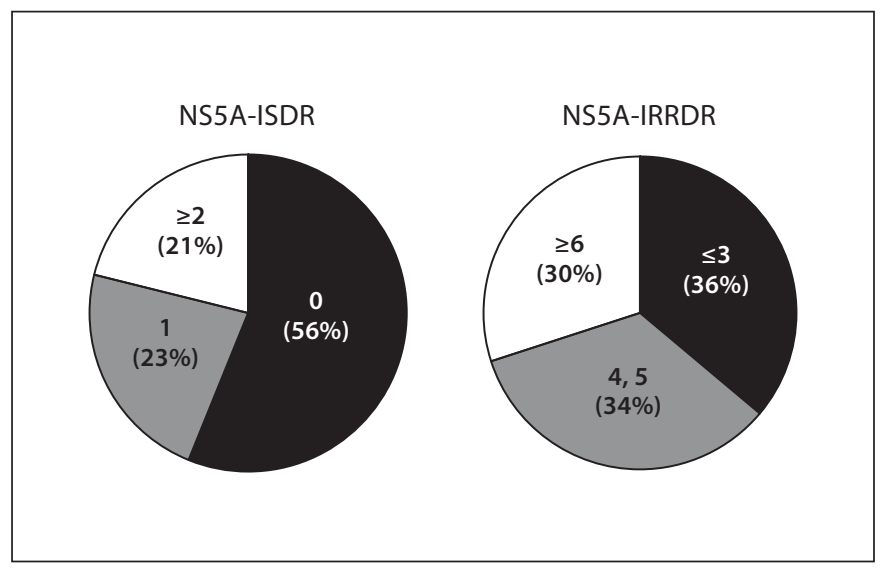

Fig. 1. The number of aa substitutions in NS5A-ISDR and NS5AIRRDR. The percentage of patients with $\leq 1$ aa substitution in ISDR (WT) was 79\%.

thermore, the number of aa substitutions in IRRDR of 123 patients with Arg70 (median 5) was also not significantly different from that of 77 patients with $G \ln 70$ (His70) (median 4) (fig. 3b).

Concerning the substitution of core aa 91, the number of aa substitutions in ISDR of 240 patients with Leu91 (median 1) was significantly higher than that of $161 \mathrm{pa}-$ tients with Met91 (median 0) (p < 0.001) (fig. 3c). Furthermore, the number of aa substitutions in IRRDR of 111 patients with Leu91 (median 5) was significantly higher than that of 89 patients with Met91 (median 3) $(\mathrm{p}<0.001)$ (fig. 3d).

\section{Viremia Level and aa Substitutions in Core Region/ ISDR/IRRDR}

Concerning the number of substitutions in ISDR, viremia levels of 321 patients with WT (median 6.5) were significantly higher than those of 84 patients with nonWT (median 5.7) $(\mathrm{p}<0.001)$ (fig 4a).

Concerning the number of substitutions in IRRDR, viremia levels of 140 patients with $\leq 5$ substitutions (median 6.4) were significantly higher than those of $60 \mathrm{pa}-$ tients with $\geq 6$ (median 6.1) $(\mathrm{p}=0.027)$ (fig. 4b).

Concerning the substitution of core aa 70 , viremia levels of 265 patients with Arg70 (median 6.4) were not significantly different from those of 151 patients with Gln70 (His70) (median 6.3) (fig. 4c).

Concerning the substitution of core aa 91, viremia levels of 169 patients with Met91 (median 6.5) were significantly higher than those of 245 patients with Leu91 (median 6.2) $(\mathrm{p}=0.028)$ (fig. $4 \mathrm{~d})$.

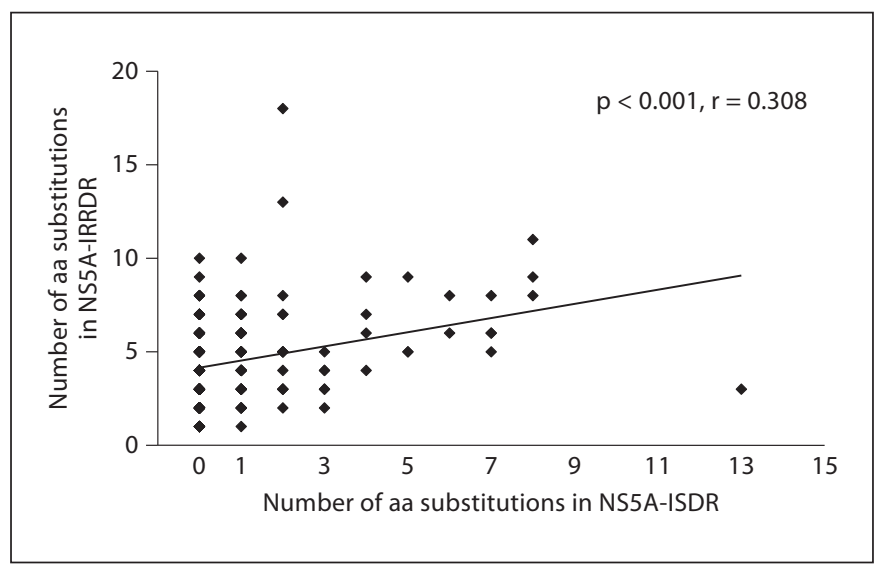

Fig. 2. Correlation between NS5A-ISDR and NS5A-IRRDR. There was a significant positive correlation between the number of aa substitutions in ISDR and that in IRRDR $(r=0.308, p<0.001)$.

Thus, levels of viremia were influenced by aa substitutions in core aa 91 and ISDR/IRRDR.

\section{Treatment Response according to the Number of aa}

Substitutions in IRRDR

Concerning the number of aa substitutions in IRRDR, a significantly higher proportion of patients with $\geq 4$ aa substitutions (58\%) showed SVR compared to patients with $\leq 3(42 \%)(p=0.039)$. In contrast, the SVR rate was not significantly different between patients with $\leq 4$ (49\%) and those with $\geq 5$ (57\%) aa substitutions. Likewise, the SVR rate was not significantly different between patients with $\leq 5(51 \%)$ and those with $\geq 6$ (55\%) aa substitutions (fig. $5 \mathrm{a}$ ).

The ETR rate was not significantly different between patients with $\leq 3(74 \%)$ and those with $\geq 4(82 \%)$ aa substitutions, nor between patients with $\leq 4(76 \%)$ and those with $\geq 5$ (83\%). Likewise, the ETR rate was not significantly different between those with $\leq 5(79 \%)$ and those with $\geq 6$ ( $80 \%$ ) aa substitutions (fig. 5b).

The SVR rate after ETR was not significantly different between patients with $\leq 3(61 \%)$ and those with $\geq 4(74 \%)$ aa substitutions, nor between patients with $\leq 4(67 \%)$ and those with $\geq 5$ (72\%). Likewise, they were not significantly different between patients with $\leq 5$ (67\%) and those with $\geq 6$ (75\%) aa substitutions (fig. 5c).

Thus, it was useful as predictor of SVR to categorize into two groups of $\leq 4$ and $\geq 5$ aa substitutions by univariate analysis. However, the ETR and SVR after ETR rates were not significantly different according to the number of aa substitutions in IRRDR. 


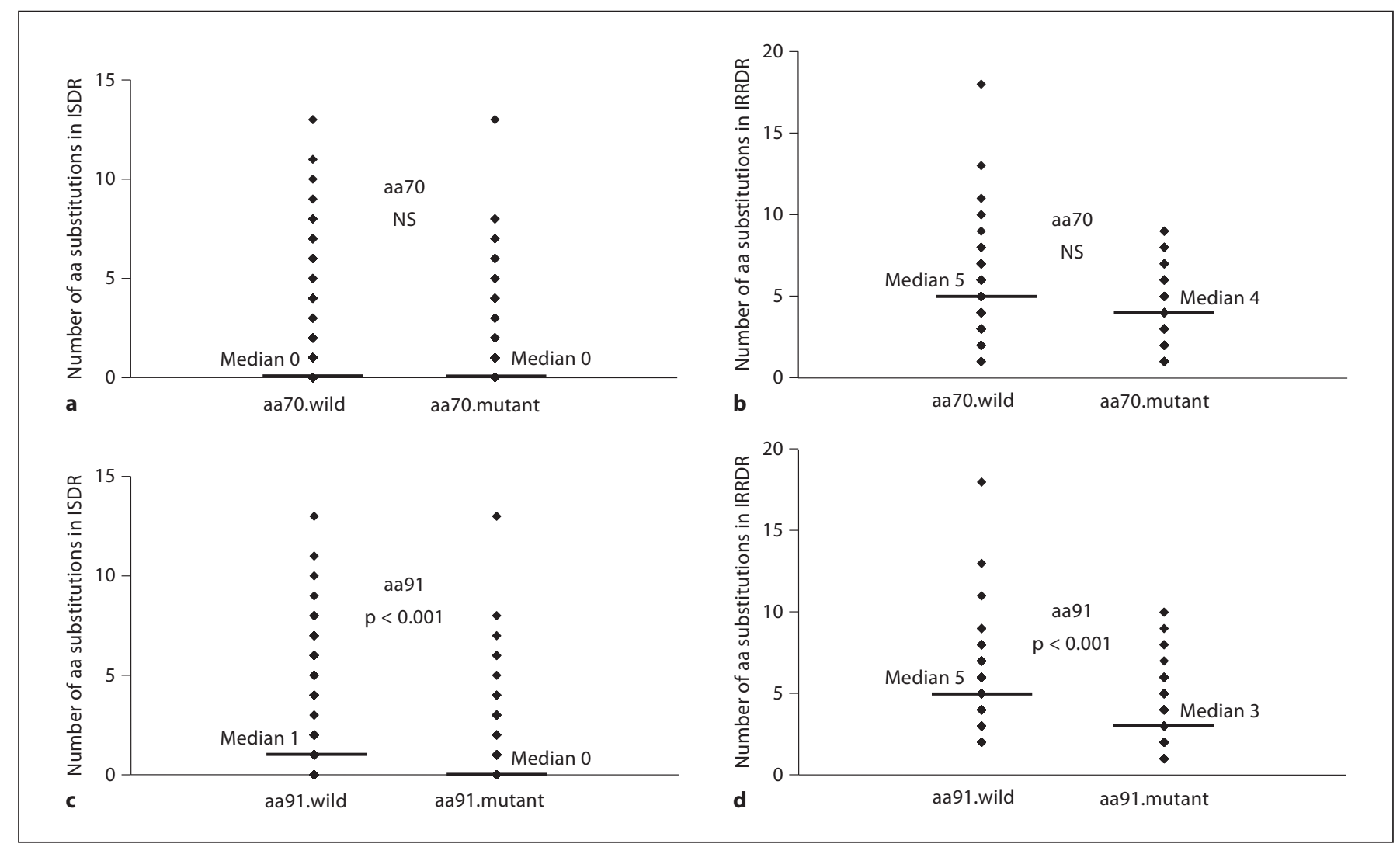

Fig. 3. aa substitutions in the core region and NS5A-ISDR/IRRDR. a, b Concerning the substitution of core aa 70, the number of aa substitutions in ISDR/IRRDR of patients with Arg70 was not significantly different from that of patients with Gln70 (His70). c, d Concerning the substitution of core aa 91, the number of aa substitutions in ISDR/IRRDR of patients with Leu91 was significantly higher than that of patients with Met91 ( $\mathrm{p}<$ $0.001)$.

\section{Predictors of SVR as Determined by Uni- and \\ Multivariate Analyses}

Univariate analysis identified 15 parameters that correlate with SVR: gender (male sex; $\mathrm{p}<0.001)$, age $(<55$ years; $\mathrm{p}<0.001)$, ribavirin dose $(\geq 11.0 \mathrm{mg} / \mathrm{kg}$; $\mathrm{p}=0.006)$, AST ( $<58$ IU/l; $\mathrm{p}=0.039)$, leukocyte count $\left(\geq 4,500 / \mathrm{mm}^{3}\right.$; $\mathrm{p}=0.043)$, hemoglobin $(\geq 14.0 \mathrm{~g} / \mathrm{dl} ; \mathrm{p}=0.001)$, platelet count $\left(\geq 15.0 \times 10^{4} / \mathrm{mm}^{3} ; \mathrm{p}<0.001\right)$, GGT $(<50 \mathrm{IU} / \mathrm{l}$; $\mathrm{p}=0.028)$, uric acid $(\geq 5.5 \mathrm{mg} / \mathrm{dl} ; \mathrm{p}=0.005)$, level of viremia $(<6.0 \log \mathrm{IU} / \mathrm{ml} ; \mathrm{p}<0.001), \alpha$-fetoprotein $(<10$ $\mu \mathrm{g} / \mathrm{l} ; \mathrm{p}<0.001$ ), genetic variation in rs8099917 (genotype TT; p < 0.001), substitution of aa 70 (Arg70; $p<0.001)$, the number of aa substitutions in ISDR (non-WT; $p<0.001$ ) and IRRDR $(\geq 4 ; p=0.039)$. Figure 6 shows the SVR rate according to aa substitution in the core/NS5A region and genetic variation near IL28B by univariate analysis.

Multivariate analysis that included the above variables identified 3 parameters that independently influenced
SVR: genetic variation in rs8099917 (genotype TT; $\mathrm{p}<$ 0.001 ), gender (male sex; $p<0.001$ ), and the number of aa substitutions in ISDR (non-WT; $\mathrm{p}=0.027$ ) (table 2).

\section{Predictors of ETR as Determined by Uni- and \\ Multivariate Analyses}

Univariate analysis identified 14 parameters that correlated with ETR: gender (male sex; $\mathrm{p}=0.001)$, age $(<55$ years; $\mathrm{p}=0.004)$, AST $(<39 \mathrm{IU} / \mathrm{l} ; \mathrm{p}=0.027)$, hemoglobin $(\geq 14.0 \mathrm{~g} / \mathrm{dl} ; \mathrm{p}=0.035)$, platelet count $\left(\geq 15.0 \times 10^{4} / \mathrm{mm}^{3}\right.$; $\mathrm{p}<0.001)$, albumin $(\geq 3.9 \mathrm{~g} / \mathrm{dl} ; \mathrm{p}=0.014), \mathrm{GGT}(<50 \mathrm{IU} / \mathrm{l}$; $\mathrm{p}<0.001)$, uric acid $(\geq 5.5 \mathrm{mg} / \mathrm{dl} ; \mathrm{p}=0.003)$, level of vire$\mathrm{mia}(<6.0 \log \mathrm{IU} / \mathrm{ml} ; \mathrm{p}=0.001)$, low-density lipoprotein cholesterol $(\geq 85 \mathrm{mg} / \mathrm{dl} ; \mathrm{p}=0.004), \alpha$-fetoprotein $(<10$ $\mu \mathrm{g} / \mathrm{l} ; \mathrm{p}<0.001$ ), genetic variation in rs8099917 (genotype TT; $\mathrm{p}<0.001$ ), substitution of aa 70 (Arg70; $\mathrm{p}<0.001$ ), and the number of aa substitutions in ISDR (non-WT; $\mathrm{p}=0.021$ ). Figure 7 shows the ETR rate according to aa 


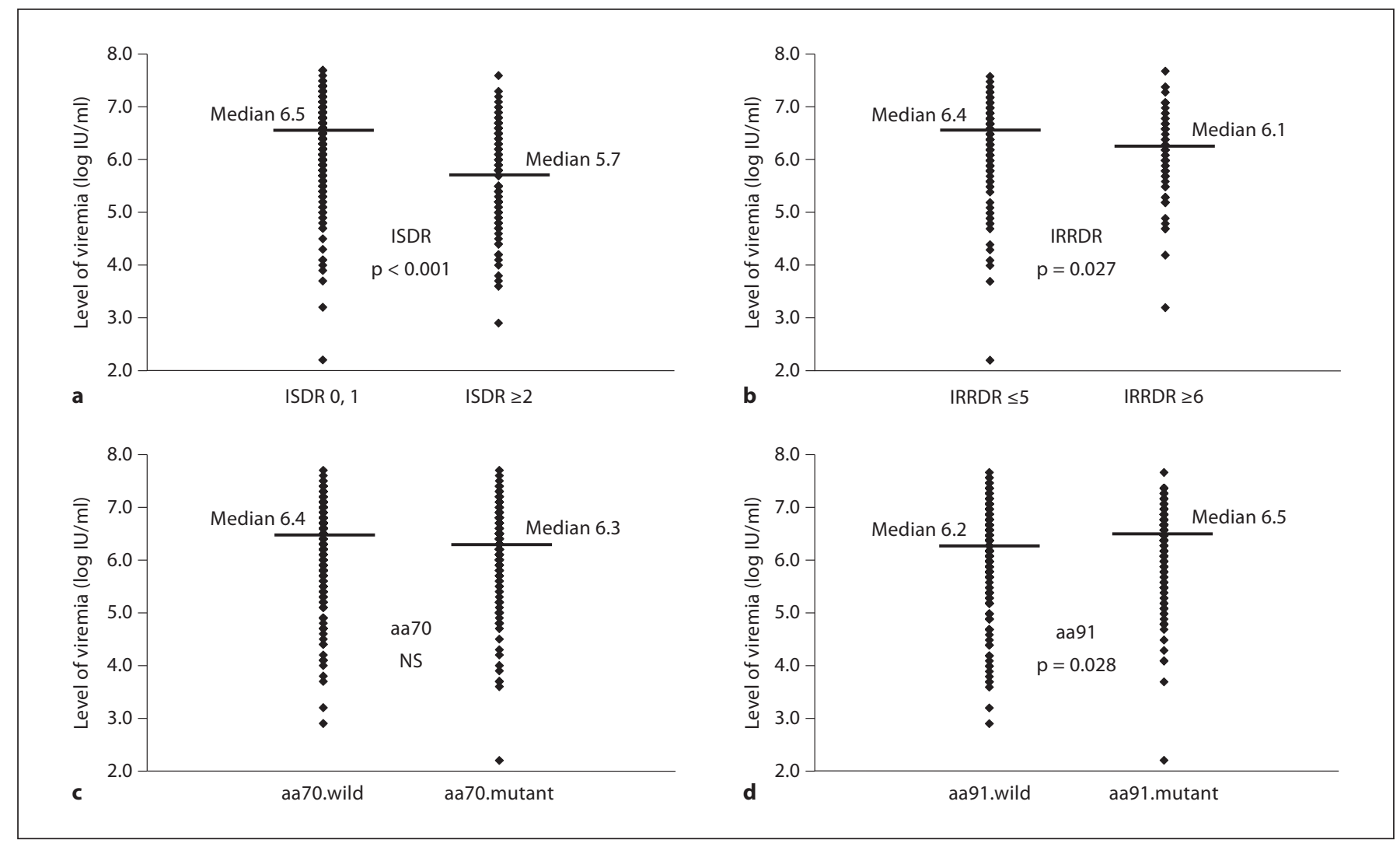

Fig. 4. Viremia level and aa substitutions in core region/ISDR/ IRRDR. a Concerning the number of substitutions in ISDR, viremia levels of patients with WT were significantly higher than those of patients with non-WT $(\mathrm{p}<0.001)$. b Concerning the number of substitutions in IRRDR, viremia levels of patients with $\leq 5$ aa substitutions were significantly higher levels than those of patients with $\geq 6$ ( $p=0.027)$. c Concerning the substitution of core aa 70, viremia levels of patients with Arg70 were not significantly different from those of patients with Gln70 (His70). d Concerning the substitution of core aa 91, viremia levels of patients with Met91 were significantly higher than those of patients with Leu91 ( $\mathrm{p}=0.028$ ). Thus, levels of viremia might be influenced by aa substitutions in core aa 91 and ISDR/IRRDR.

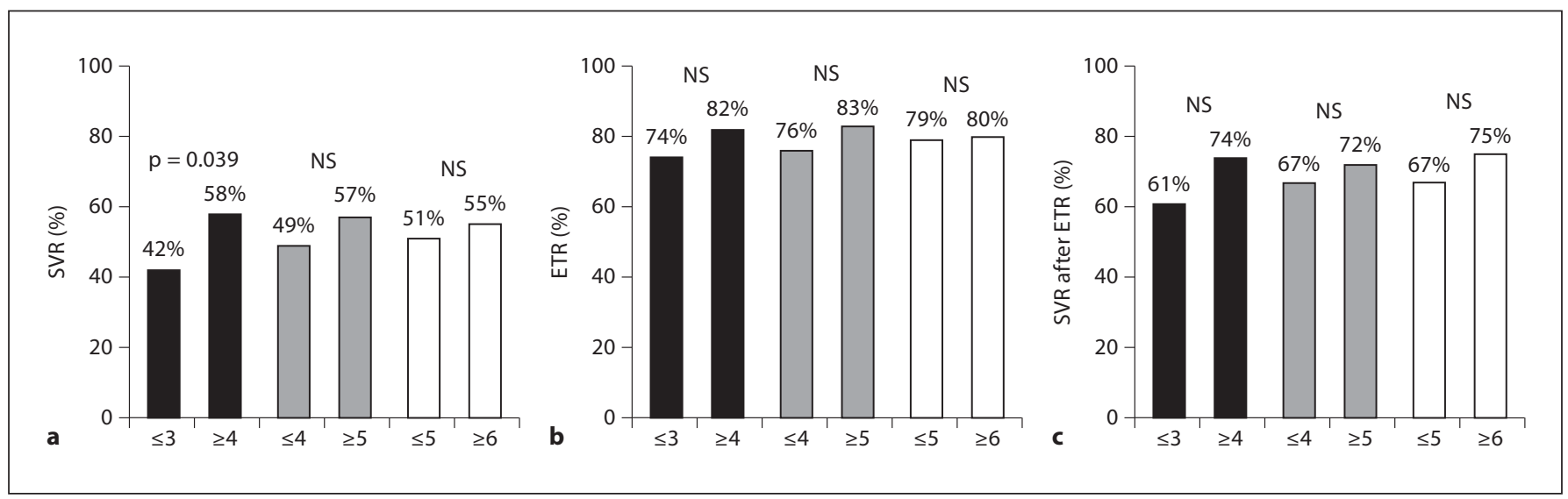

Fig. 5. Treatment response according to the number of aa substitutions in NS5A-IRRDR. a A significantly higher proportion of patients with $\geq 4$ (58\%) aa substitutions showed SVR compared to patients with $\leq 3(42 \%)(\mathrm{p}=0.039)$, and it was useful as predictor of SVR to categorize into two groups of $\leq 4$ and $\geq 5$ aa substitutions by univariate analysis. b, c ETR and SVR after ETR rates were not significantly different according to the number of aa substitutions in IRRDR. 
Fig. 6. SVR rate according to aa substitution in core/NS5A region and genetic variation near $I L 28 B$ by univariate analysis.
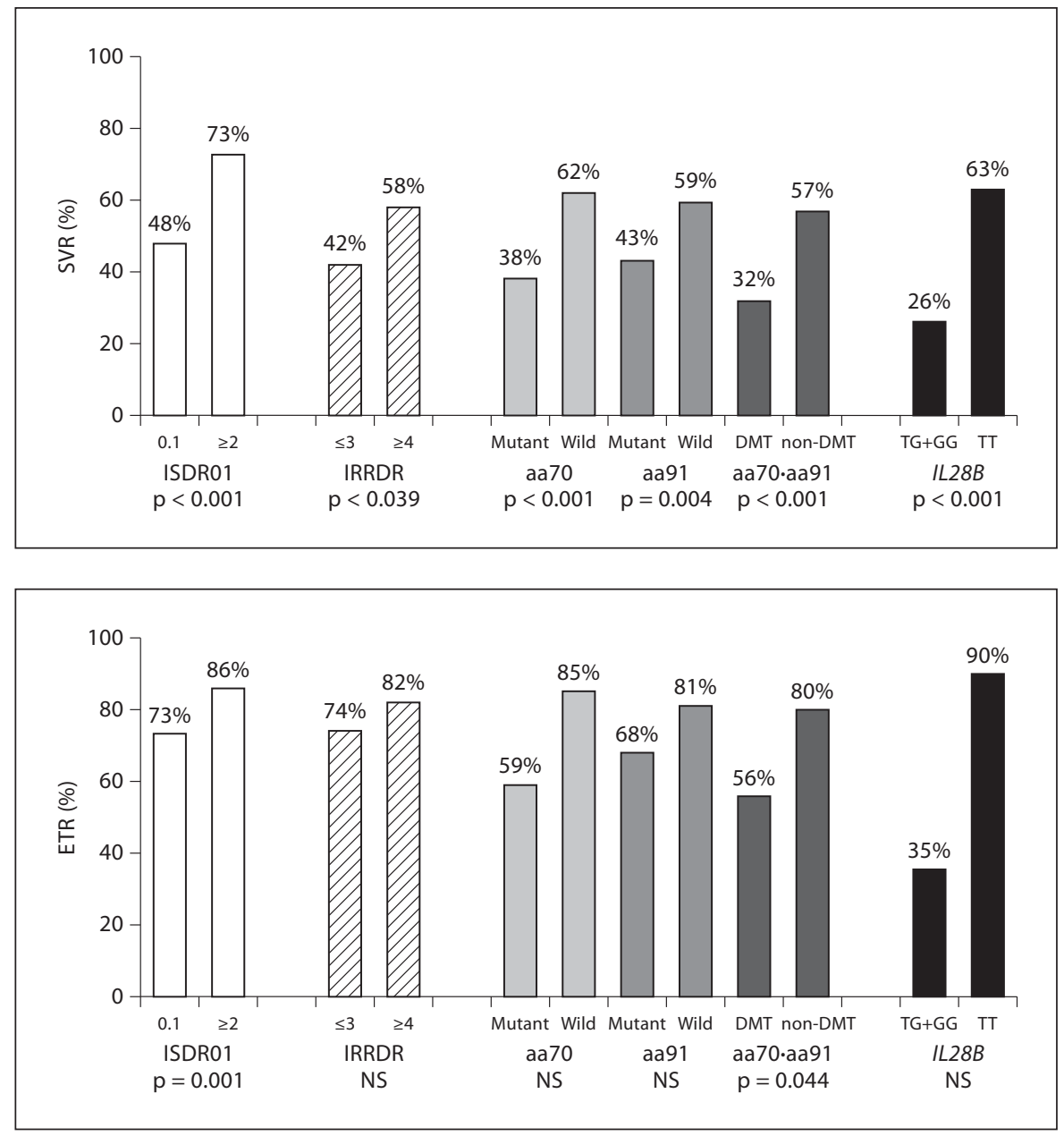

Fig. 7. ETR rate according to aa substitution in core/NS5A region and genetic variation near $I L 28 B$ by univariate analysis.
Table 3. Factors associated with ETR response to 48-week IFN + ribavirin combination therapy in patients infected with HCV-1b, identified by multivariate analysis

\begin{tabular}{|c|c|c|c|}
\hline Factor & Category & $\begin{array}{l}\text { OR } \\
(95 \% \mathrm{CI})\end{array}$ & $\mathrm{p}$ \\
\hline \multirow{2}{*}{$\begin{array}{l}\text { rs8099917 } \\
\text { genotype }\end{array}$} & 1: $\mathrm{TG}+\mathrm{GG}$ & 1 & \\
\hline & 2: TT & $18.2(6.29-52.6)$ & $<0.001$ \\
\hline \multirow{2}{*}{$\begin{array}{l}\text { Level of viremia } \\
\log \mathrm{IU} / \mathrm{ml}\end{array}$} & $1: \geq 6.0$ & 1 & \\
\hline & $2:<6.0$ & $9.20(2.59-32.6)$ & 0.001 \\
\hline \multirow[t]{2}{*}{ Core aa 70} & 1: $\mathrm{Gln} 70$ (His70) & 1 & \\
\hline & 2: Arg70 & $4.68(1.65-13.3)$ & 0.004 \\
\hline \multirow{2}{*}{$\begin{array}{l}\text { Serum albumin } \\
\text { g/dl }\end{array}$} & $1:<3.9$ & 1 & \\
\hline & $2: \geq 3.9$ & $3.08(1.11-8.47)$ & 0.030 \\
\hline
\end{tabular}

Only variables that achieved statistical significance $(\mathrm{p}<0.05)$ on multivariate logistic regression are shown. 
Fig. 8. SVR after ETR rate according to aa substitution in core/NS5A region and genetic variation near IL $28 B$ by univariate analysis.

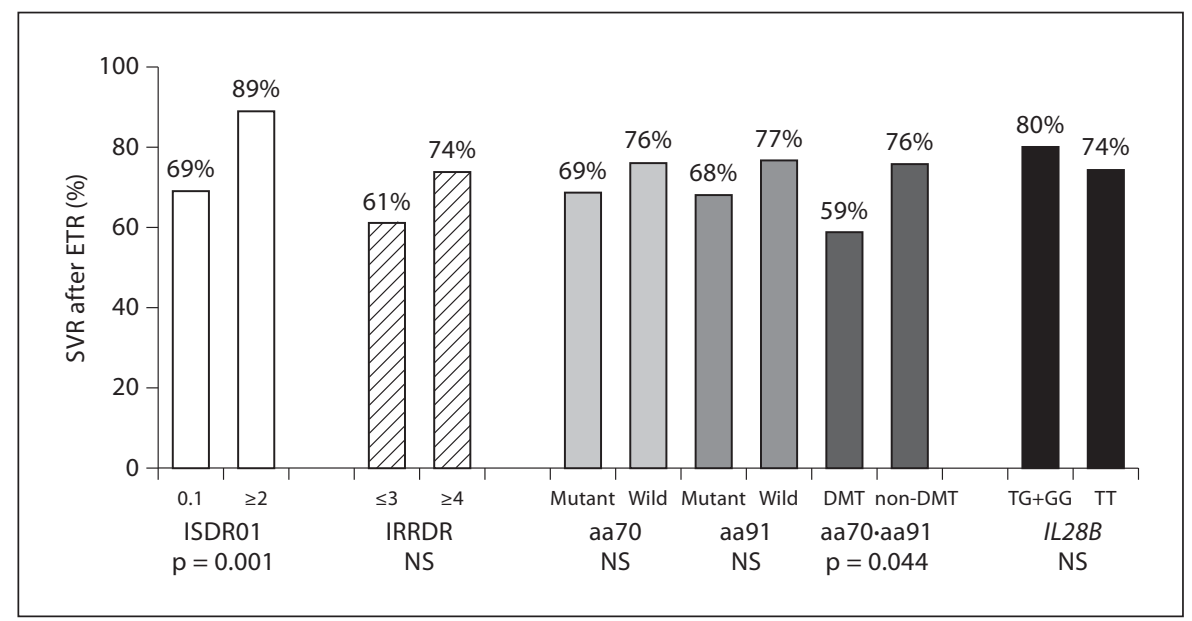

substitution in the core/NS5A region and genetic variation near $I L 28 B$ by univariate analysis.

Multivariate analysis that included the above variables identified 4 parameters that independently influenced ETR: genetic variation in rs8099917 (genotype TT; $\mathrm{p}<$ $0.001)$, level of viremia $(<6.0 \log \mathrm{IU} / \mathrm{ml} ; \mathrm{p}=0.001)$, substitution of aa 70 (Arg70; $\mathrm{p}=0.004)$, and albumin $(\geq 3.9$ $\mathrm{g} / \mathrm{dl} ; \mathrm{p}=0.030)($ table 3$)$.

\section{Predictors of SVR after ETR as Determined by}

Uni- and Multivariate Analyses

Univariate analysis identified 11 parameters that influenced SVR after ETR: gender (male sex; $\mathrm{p}<0.001$ ), age $(<55$ years; $\mathrm{p}<0.001)$, ribavirin dose $(\geq 11.0 \mathrm{mg} / \mathrm{kg}$; $\mathrm{p}=$ $0.025)$, leukocyte count $\left(\geq 4,500 / \mathrm{mm}^{3} ; \mathrm{p}=0.033\right)$, hemoglobin $(\geq 14.0 \mathrm{~g} / \mathrm{dl} ; \mathrm{p}=0.025)$, platelet count $(\geq 15.0 \times$ $\left.10^{4} / \mathrm{mm}^{3} ; \mathrm{p}=0.001\right)$, level of viremia $(<6.0 \log \mathrm{IU} / \mathrm{ml} ; \mathrm{p}=$ $0.020)$, total cholesterol $(<170 \mathrm{mg} / \mathrm{dl} ; \mathrm{p}=0.017), \alpha$-fetoprotein $(<10 \mu \mathrm{g} / \mathrm{l} ; \mathrm{p}=0.004)$, substitution of aa 70 and 91 (Arg70 and/or Leu91; p = 0.044), and the number of aa substitutions in ISDR (non-WT; $p=0.001$ ). Figure 8 shows the SVR after ETR rate according to aa substitution in the core/NS5A region and genetic variation near IL28B by univariate analysis.

Multivariate analysis that included the above variables identified 6 parameters that independently influenced the SVR after ETR: gender (male sex; $\mathrm{p}<0.001$ ), ribavirin dose $(\geq 11.0 \mathrm{mg} / \mathrm{kg} ; \mathrm{p}=0.002)$, the number of aa substitutions in ISDR (non-WT; $\mathrm{p}=0.012$ ), substitution of aa 70 and 91 (Arg70 and/or Leu91; $\mathrm{p}=0.023$ ), platelet count $\left(\geq 15.0 \times 10^{4} / \mathrm{mm}^{3} ; \mathrm{p}=0.033\right)$, and $\alpha$-fetoprotein $(<10$ $\mu \mathrm{g} / \mathrm{l} ; \mathrm{p}=0.042)($ table 4$)$.
Comparison of Factors Associated with Treatment Efficacy Identified by Multivariate Analysis

Table 5 shows the variables that achieved statistical significance on multivariate logistic regression for each evaluation of treatment efficacy. Rs8099917 genotype was an important predictor of ETR and SVR. With regard to viral factors, core region was an important predictor of ETR, and SVR after ETR. ISDR was an important predictor of SVR, and SVR after ETR. Level of viremia was an important predictor of ETR. Thus, genetic variation near $I L 28 B$ and viral factors (core region, ISDR, and level of viremia) were important predictors of treatment efficacy. Furthermore, gender, $\alpha$-fetoprotein, albumin, and platelet count were also identified as other important predictors of treatment efficacy, in addition to genetic variation near IL28B and viral factors.

\section{Discussion}

Using multivariate analysis, the present study identified viral- (aa substitutions in core aa 70/91 and NS5AISDR/IRRDR) and host-related factors (genetic variation near IL28B gene) that influenced treatment efficacy to 48-week IFN/ribavirin combination therapy, which is in agreement with recent findings [22, 23]. Identification of these viral and host factors before the start of IFN/ribavirin combination therapy should help to select better therapeutic regimens, including triple therapy of telaprevir/PEG-IFN/ribavirin [24-26], for those patients who are less likely to achieve SVR.

According to the number of substitutions in ISDR, a previous report showed that levels of viremia were sig- 
Table 4. Factors associated with SVR in patients who achieved ETR response to 48-week IFN + ribavirin combination therapy in patients infected with HCV-1b, identified by multivariate analysis

\begin{tabular}{|c|c|c|c|}
\hline Factor & Category & OR $(95 \% \mathrm{CI})$ & $\mathrm{p}$ \\
\hline Gender & $\begin{array}{l}\text { 1: Female } \\
\text { 2: Male }\end{array}$ & $\begin{array}{l}1 \\
4.27(2.15-8.55)\end{array}$ & $<0.001$ \\
\hline $\begin{array}{l}\text { Ribavirin } \\
\text { dose, } \mathrm{mg} / \mathrm{kg}\end{array}$ & $\begin{array}{l}1:<11.0 \\
2: \geq 11.0\end{array}$ & $\begin{array}{l}1 \\
2.95(1.48-5.86)\end{array}$ & 0.002 \\
\hline $\begin{array}{l}\text { ISDR of } \\
\text { NS5A }\end{array}$ & $\begin{array}{l}\text { 1: WT } \\
\text { 2: Non-WT }\end{array}$ & $\begin{array}{l}1 \\
4.00(1.35-11.8)\end{array}$ & 0.012 \\
\hline $\begin{array}{l}\text { Core aa } 70 \\
\text { and } 91\end{array}$ & $\begin{array}{l}\text { 1: Gln70 (His70) and Met91 } \\
\text { 2: Arg70 and/or Leu91 }\end{array}$ & $\begin{array}{l}1 \\
2.96(1.16-7.52)\end{array}$ & 0.023 \\
\hline $\begin{array}{l}\text { Platelet count } \\
\times 10^{4} / \mathrm{mm}^{3}\end{array}$ & $\begin{array}{l}1:<15.0 \\
2: \geq 15.0\end{array}$ & $\begin{array}{l}1 \\
2.19(1.07-4.50)\end{array}$ & 0.033 \\
\hline $\begin{array}{l}\alpha \text {-Fetoprotein } \\
\mu \mathrm{g} / \mathrm{l}\end{array}$ & $\begin{array}{l}1: \geq 10 \\
2:<10\end{array}$ & $\begin{array}{l}1 \\
2.66(1.04-6.80)\end{array}$ & 0.042 \\
\hline
\end{tabular}

Only variables that achieved statistical significance $(\mathrm{p}<0.05)$ on multivariate logistic regression are shown.

Table 5. Comparison of factors associated with efficacy of 48-week IFN + ribavirin combination therapy in patients infected with HCV-1b, identified by multivariate analysis

\begin{tabular}{llll}
\hline Factor & ETR response (at 48 weeks) & SVR after ETR response & SVR \\
\hline IL28B & $\begin{array}{l}\text { rs8099917 } \\
\mathrm{p}<0.001,18.2(6.29-52.6)^{\mathrm{a}}\end{array}$ & $\mathrm{rs8099917}$ \\
& Core aa 70 & Core aa 70 and 91 $<0.001,16.7(4.54-61.3)^{\mathrm{a}}$ \\
\hline Virus & $\mathrm{p}=0.004,4.68(1.65-13.3)^{\mathrm{a}}$ & $\mathrm{p}=0.023,2.96(1.16-7.52)^{\mathrm{a}}$ & \\
& Level of viremia & ISDR & ISDR \\
& $\mathrm{p}=0.001,9.20(2.59-32.6)^{\mathrm{a}}$ & $\mathrm{p}=0.012,4.00(1.35-11.8)^{\mathrm{a}}$ & $\mathrm{p}=0.027,5.68(1.22-26.3)^{\mathrm{a}}$ \\
\hline Others & Albumin & $\alpha$-Fetoprotein & \\
& $\mathrm{p}=0.030,3.08(1.11-8.47)^{\mathrm{a}}$ & $\mathrm{p}=0.042,2.66(1.04-6.80)^{\mathrm{a}}$ & \\
& & Platelet count & \\
& & $\mathrm{p}=0.033,2.19(1.07-4.50)^{\mathrm{a}}$ & \\
& & Gender & Gender \\
& $\mathrm{p}<0.001,4.27(2.15-8.55)^{\mathrm{a}}$ & $\mathrm{p}<0.001,10.5(3.47-32.3)^{\mathrm{a}}$ \\
& & Ribavirin dose & \\
& & $\mathrm{p}=0.002,2.95(1.48-5.86)^{\mathrm{a}}$ & \\
\hline
\end{tabular}

Only variables that achieved statistical significance $(\mathrm{p}<0.05)$ on multivariate logistic regression are shown. ${ }^{a}$ OR $(95 \%$ CI).

nificantly lower in patients with non-WT of ISDR than in those with WT [8]. The present study indicated that substitution of IRRDR and core aa 91, in addition to substitution of ISDR, also significantly influenced levels of viremia. Furthermore, there was a significant positive correlation between the number of aa substitutions in
ISDR and those in IRRDR, and the number of aa substitutions in ISDR/IRRDR of patients with Leu91 was significantly higher than that of patients with Met91. To our knowledge, this is the first report of the relationship between viremia levels and aa substitutions in core region/ ISDR/IRRDR. This result might be interpreted to mean 
that core aa 91/ISDR/IRRDR might be associated with viremia levels involved in resistance to combination therapy. Further studies that examine the functional impact of aa substitutions to combination therapy should be conducted to confirm the above finding.

The present results showed that $\alpha$-fetoprotein, albumin, platelet count, and gender were predictors of virological response to IFN/ribavirin combination therapy. Previous data indicated that absence of advanced liver fibrosis was a positive predictor of SVR to IFN monotherapy and IFN/ribavirin combination therapy $[2,3,13$, 27-29], and that advanced liver fibrosis was usually associated with higher levels of $\alpha$-fetoprotein, and lower levels of albumin and platelet count [1,3, 30-32]. Furthermore, gender is also a predictor of treatment response to IFN/ ribavirin combination therapy $[2,3,14]$. In the present study based on a large number of patients, histopathological changes in the liver and gender were identified as independent predictors of virological response, in addition to genetic variation near IL28B and viral factors (core region, ISDR, and level of viremia).

In a previous study, multivariate analysis identified core region, gender, and stage of liver fibrosis as parameters that independently influenced the SVR of patients who achieved early virological response, but ISDR was not entered into uni- and multivariate analysis [3]. To our knowledge, the present study based on multivariate analysis is the first report to identify ISDR as pretreatment predictor of SVR after ETR to combination therapy. Interestingly, ISDR was not a predictor of ETR, but was a significant predictor of SVR to combination therapy. Thus, the underlying mechanisms of failure to develop SVR in those patients who achieve HCV-RNA negativity remain unclear. Further studies that examine the impact of aa substitutions of ISDR to combination therapy should be conducted to confirm the above finding.

One limitation of the present study was that aa substitutions in areas other than the core region and NS5AISDR/IRRDR of the HCV genome were not examined. Other limitations were differences in host factors including race $[24,33,34]$ and differences in viral factors, such as the distribution of HCV-1a or - $1 \mathrm{~b}$, and geographic diversities of HCV-1b [35]. Further large-scale prospective studies are necessary to investigate whether the present results relate to the efficacy of 48-week IFN/ribavirin combination therapy, and further understanding of the complex interaction between virus- and host- related factors should facilitate the development of more effective therapeutic regimens.

\section{Acknowledgement}

This study was supported in part by a Grant-in-Aid from the Ministry of Health, Labor and Welfare, Japan.

\section{References}

1 Akuta N, Suzuki F, Sezaki H, Suzuki Y, Hosaka T, Someya T, Kobayashi M, Saitoh S, Watahiki S, Sato J, Matsuda M, Kobayashi M, Arase Y, Ikeda K, Kumada H: Association of amino acid substitution pattern in core protein of hepatitis $\mathrm{C}$ virus genotype $\mathrm{lb}$ high viral load and non-virological response to interferon-ribavirin combination therapy. Intervirology 2005;48:372-380.

-2 Akuta N, Suzuki F, Kawamura Y, Yatsuji H, Sezaki H, Suzuki Y, Hosaka T, Kobayashi M, Kobayashi M, Arase Y, Ikeda K, Kumada H: Predictive factors of early and sustained responses to peginterferon plus ribavirin combination therapy in Japanese patients infected with hepatitis $C$ virus genotype $1 \mathrm{~b}$ : amino acid substitutions in the core region and lowdensity lipoprotein cholesterol levels. J Hepatol 2007;46:403-410.

-3 Akuta N, Suzuki F, Kawamura Y, Yatsuji H, Sezaki H, Suzuki Y, Hosaka T, Kobayashi M, Kobayashi M, Arase Y, Ikeda K, Kumada H: Predictors of viral kinetics to peginterferon plus ribavirin combination therapy in Japanese patients infected with hepatitis $C$ virus genotype 1b. J Med Virol 2007;79:1686-1695.

4 Donlin MJ, Cannon NA, Yao E, Li J, Wahed A, Taylor MW, Belle SH, Di Bisceglie AM, Aurora R, Tavis JE: Pretreatment sequence diversity differences in the full-length hepatitis $\mathrm{C}$ virus open reading frame correlate with early response to therapy. J Virol 2007; 81:8211-8224.

5 Akuta N, Suzuki F, Kawamura Y, Yatsuji H, Sezaki H, Suzuki Y, Hosaka T, Kobayashi M, Kobayashi M, Arase Y, Ikeda K, Kumada H: Amino acid substitutions in the hepatitis $\mathrm{C}$ virus core region are the important predictor of hepatocarcinogenesis. Hepatology 2007; 46:1357-1364

-6 Fishman SL, Factor SH, Balestrieri C, Fan X, Dibisceglie AM, Desai SM, Benson G, Branch AD: Mutations in the hepatitis $\mathrm{C}$ virus core gene are associated with advanced liver disease and hepatocellular carcinoma. Clin Cancer Res 2009;15:3205-3213.
7 Enomoto N, Sakuma I, Asahina Y, Kurosaki M, Murakami T, Yamamoto C, Izumi N, Marumo F, Sato C: Comparison of fulllength sequences of interferon sensitive and resistant hepatitis $C$ virus $1 \mathrm{~b}$. Sensitivity to interferon is conferred by amino acid substitutions in the NS5A region. J Clin Invest $1995 ; 96: 224-230$

8 Enomoto N, Sakuma I, Asahina Y, Kurosaki M, Murakami T, Yamamoto C, Ogura Y, Izumi N, Marumo F, Sato C: Mutations in the nonstructural protein $5 \mathrm{~A}$ gene and response to interferon in patients with chronic hepatitis $\mathrm{C}$ virus $1 \mathrm{~b}$ infection. N Engl J Med 1996; 334:77-81.

9 El-Shamy A, Sasayama M, Nagano-Fujii M, Sasase N, Imoto S, Kim SR, Hotta H: Prediction of efficient virological response to pegylated interferon/ribavirin combination therapy by NS5A sequences of hepatitis C virus and anti-NS5A antibodies in pre-treatment sera. Microbiol Immunol 2007;51:471482 . 
-10 El-Shamy A, Nagano-Fujii M, Sasase N, Imoto $\mathrm{S}, \mathrm{Kim}$ SR, Hotta H: Sequence variation in hepatitis $\mathrm{C}$ virus nonstructural protein $5 \mathrm{~A}$ predicts clinical outcome of pegylated interferon/ribavirin combination therapy. Hepatology 2008;48:38-47.

- 11 Shirakawa H, Matsumoto A, Joshita S, Komatsu M, Tanaka N, Umemura T, Ichijo T, Yoshizawa K, Kiyosawa K, Tanaka E: Nagano Interferon Treatment Research Group: Pretreatment prediction of virological response to peginterferon plus ribavirin therapy in chronic hepatitis $\mathrm{C}$ patients using viral and host factors. Hepatology 2008;48:1753-1760.

12 Mori N, Imamura M, Kawakami Y, Saneto H, Kawaoka T, Takaki S, Aikata H, Takahashi S, Chayama K: Hiroshima Liver Study Group: Randomized trial of high-dose interferon- $\alpha-2 b$ combined with ribavirin in patients with chronic hepatitis C: Correlation between amino acid substitutions in the core/NS5A region and virological response to interferon therapy. J Med Virol 2009;81: 640-649.

13 Ge D, Fellay J, Thompson AJ, Simon JS, Shianna KV, Urban TJ, Heinzen EL, Qiu P, Bertelsen AH, Muir AJ, Sulkowski M, McHutchison JG, Goldstein DB: Genetic variation in IL28B predicts hepatitis C treatment-induced viral clearance. Nature 2009;461:399401.

- 14 Tanaka Y, Nishida N, Sugiyama M, Kurosaki M, Matsuura K, Sakamoto N, Nakagawa M, Korenaga M, Hino K, Hige S, Ito Y, Mita E, Tanaka E, Mochida S, Murawaki Y, Honda M, Sakai A, Hiasa Y, Nishiguchi S, Koike A, Sakaida I, Imamura M, Ito K, Yano K, Masaki N, Sugauchi F, Izumi N, Tokunaga K, Mizokami M: Genome-wide association of $I L 28 B$ with response to pegylated interferon$\alpha$ and ribavirin therapy for chronic hepatitis C. Nat Genet 2009;41:1105-1109.

-15 Suppiah V, Moldovan M, Ahlenstiel G, Berg T, Weltman M, Abate ML, Bassendine M, Spengler U, Dore GJ, Powell E, Riordan S, Sheridan D, Smedile A, Fragomeli V, Müller T, Bahlo M, Stewart GJ, Booth DR, George J: IL28B is associated with response to chronic hepatitis $C$ interferon- $\alpha$ and ribavirin therapy. Nat Genet 2009;41:1100-1104.

-16 Rauch A, Kutalik Z, Descombes P, Cai T, Di Iulio J, Mueller T, Bochud M, Battegay M, Bernasconi E, Borovicka J, Colombo S, Cerny A, Dufour JF, Furrer H, Günthard HF, Heim M, Hirschel B, Malinverni R, Moradpour D, Müllhaupt B, Witteck A, Beckmann JS, Berg T, Bergmann S, Negro F, Telenti A, Bochud PY: Swiss Hepatitis C Cohort Study; Swiss HIV Cohort Study: Genetic variation in $I L 28 B$ is associated with chronic hepatitis $\mathrm{C}$ and treatment failure: a genome-wide association study. Gastroenterology 2010;138: $1338-1345$.
17 Thomas DL, Thio CL, Martin MP, Qi Y, Ge D, O'Huigin C, Kidd J, Kidd K, Khakoo SI, Alexander G, Goedert JJ, Kirk GD, Donfield SM, Rosen HR, Tobler LH, Busch MP, McHutchison JG, Goldstein DB, Carrington M: Genetic variation in IL28B and spontaneous clearance of hepatitis $\mathrm{C}$ virus. Nature 2009;461:798-801.

18 Akuta N, Suzuki F, Hirakawa M, Kawamura Y, Yatsuji H, Sezaki H, Suzuki Y, Hosaka T, Kobayashi M, Kobayashi M, Saitoh S, Arase Y, Ikeda K, Chayama K, Nakamura Y, Kumada $\mathrm{H}$ : Amino acid substitution in $\mathrm{HCV}$ core region and genetic variation near the interleukin-28B gene predict viral response to telaprevir with peginterferon and ribavirin. Hepatology 2010;52:421-429.

19 Kato N, Hijikata M, Ootsuyama Y, Nakagawa M, Ohkoshi S, Sugimura T, Shimotohno $\mathrm{K}$ : Molecular cloning of the human hepatitis $\mathrm{C}$ virus genome from Japanese patients with non-A, non-B hepatitis. Proc Natl Acad Sci USA 1990;87:9524-9528.

20 Ohnishi Y, Tanaka T, Ozaki K, Yamada R, Suzuki H, Nakamura Y: A high-throughput SNP typing system for genome-wide association studies. J Hum Genet 2001;46:471-477.

21 Suzuki A, Yamada R, Chang X, Tokuhiro S, Sawada T, Suzuki M, Nagasaki M, Nakayama-Hamada M, Kawaida R, Ono M, Ohtsuki M, Furukawa H, Yoshino S, Yukioka M, Tohma S, Matsubara T, Wakitani S, Teshima R, Nishioka Y, Sekine A, Iida A, Takahashi A, Tsunoda T, Nakamura Y, Yamamoto K: Functional haplotypes of PADI4, encoding citrullinating enzyme peptidylarginine deiminase 4 , are associated with rheumatoid arthritis. Nat Genet 2003;34:395-402.

22 Kurosaki M, Tanaka Y, Nishida N, Sakamoto N, Enomoto N, Honda M, Sugiyama M, Matsuura K, Sugauchi F, Asahina Y, Nakagawa M, Watanabe M, Sakamoto M, Maekawa S Sakai A, Kaneko S, Ito K, Masaki N, Tokunaga K, Izumi N, Mizokami M: Pre-treatment prediction of response to pegylated-interferon plus ribavirin for chronic hepatitis $\mathrm{C}$ using genetic polymorphism in IL28B and viral factors. J Hepatol 2011;54:439-448.

23 Hayes CN, Kobayashi M, Akuta N, Suzuki F, Kumada $\mathrm{H}$, Abe $\mathrm{H}$, Miki D, Imamura $\mathrm{M}$, Ochi H, Kamatani N, Nakamura Y, Chayama K: HCV substitutions and IL28B polymorphisms on outcome of peg-interferon plus ribavirin combination therapy. Gut 2011;60:261-267.

24 McHutchison JG, Everson GT, Gordon SC, Jacobson IM, Sulkowski M, Kauffman R, McNair L, Alam J, Muir AJ: PROVE1 Study Team: Telaprevir with peginterferon and ribavirin for chronic $\mathrm{HCV}$ genotype 1 infection. N Engl J Med 2009;360:1827-1838.

25 McHutchison JG, Manns MP, Muir AJ, Terrault NA, Jacobson IM, Afdhal NH, Heathcote EJ, Zeuzem S, Reesink HW, Garg J, Bsharat M, George S, Kauffman RS, Adda N, Di Bisceglie AM: PROVE3 Study Team: Telaprevir for previously treated chronic $\mathrm{HCV}$ infection. N Engl J Med 2010;362:1292-1303.
26 Hézode C, Forestier N, Dusheiko G, Ferenci $\mathrm{P}$, Pol S, Goeser T, Bronowicki JP, Bourlière M, Gharakhanian S, Bengtsson L, McNair L, George S, Kieffer T, Kwong A, Kauffman RS, Alam J, Pawlotsky JM, Zeuzem S: PROVE2 Study Team: Telaprevir and peginterferon with or without ribavirin for chronic $\mathrm{HCV}$ infection. N Engl J Med 2009;360:18391850

27 Jouet P, Roudot-Thoraval F, Dhumeaux D, Metreau JM: Comparative efficacy of interferon alfa in cirrhotic and noncirrhotic patients with non-A, non-B, C hepatitis. Gastroenterology 1994;106:686-690.

28 Poynard T, McHutchinson J, Goodman Z, Ling MH, Albrecht J: Is an 'a la carte' combination interferon alfa-2b plus ribavirin regimen possible for the first-line treatment in patients with chronic hepatitis $\mathrm{C}$ ? The ALGOVIRC Group. Hepatology 2000;31:211218.

-29 Bruno S, Camma C, Di Marco V, Rumi M, Vinci M, Camozzi M, Rebucci C, Di Bona D, Colombo M, Craxi A, Mondelli MU, Pinzello G: Peginterferon alfa-2b plus ribavirin for naïve patients with genotype 1 chronic hepatitis C: a randomized controlled trial. J Hepatol 2004;41:474-481.

30 Bayati N, Silverman AL, Gordon SC: Serum $\alpha$-fetoprotein levels and liver histology in patients with chronic hepatitis C. Am J Gastroenterol 1998;93:2452-2456.

31 Chu CW, Hwang SJ, Luo JC, Lai CR, Tsay SH, Li CP, Wu JC, Chang FY, Lee SD: Clinical, virological, and pathologic significance of elevated serum $\alpha$-fetoprotein levels in patients with chronic hepatitis C. J Clin Gastroenterol 2001;32:240-244.

>32 Hu KQ, Kyulo NL, Lim N, Elhazin B, Hillebrand DJ, Bock T: Clinical significance of elevated $\alpha$-fetoprotein in patients with chronic hepatitis $C$, but not hepatocellular carcinoma. Am J Gastroenterol 2004;99:860-865.

33 McHutchison JG, Poynard T, Pianko S, Gordon SC, Reid AE, Dienstag J, Morgan T, Yao $\mathrm{R}$, Albrecht J: The impact of interferon plus ribavirin on response to therapy in black patients with chronic hepatitis $\mathrm{C}$. The International Hepatitis Interventional Therapy Group. Gastroenterology 2000;119:13171323.

>34 Kaplan DE, Sugimoto K, Ikeda F, Stadanlick J, Valiga M, Shetty K, Reddy KR, Chang KM: $\mathrm{T}$-cell response relative to genotype and ethnicity during antiviral therapy for chronic hepatitis C. Hepatology 2005;41:1365-1375.

35 Nakano I, Fukuda Y, Katano Y, Nakano S, Kumada T, Hayakawa T: Why is the interferon sensitivity-determining region (ISDR) system useful in Japan? J Hepatol 1999;30: 1014-1022. 